Original Research Paper

\title{
Aplikasi Teknik Environmental DNA (eDNA) untuk Deteksi Spesies Cherax quadricarinatus (Von Martens 1868) Menggunakan Sampel Air
}

\author{
Vella Nurazizah Djalil ${ }^{1}$, Achmad Farajallah ${ }^{2}$, Yusli Wardiatno ${ }^{3,4 *}$ \\ ${ }^{1}$ Program Magister Biosains Hewan FMIPA Institut Pertanian Bogor \\ ${ }^{2}$ Departemen Biologi FMIPA Institut Pertanian Bogor \\ ${ }^{3}$ Departemen Manajemen Sumberdaya Perairan FPIK Institut Pertanian Bogor \\ ${ }^{4}$ Pusat Penelitian Lingkungan Hidup, Institut Pertanian Bogor
}

\author{
Article history \\ Received: 11 Juli 2018 \\ Revised: 28 Agustus 2018 \\ Accepted: 02 Oktober 2018 \\ Published: 21 November 2018 \\ *Corresponding Author: \\ Yusli Wardiatno, \\ Departemen Manajemen \\ Sumberdaya Perairan FPIK \\ Institut Pertanian Bogor \\ Indonesia \\ Email: \\ yusli@ipb.ac.id
}

\begin{abstract}
Cherax quadricarinatus is an introduced species from Australia. Fast life cycle and high tolerance for the environment cause $C$. quadricarinatus to invade aquatic ecosystems. This study aimed to apply eDNA techniques quickly for the detection of $C$. quadricarinatus. DNA extraction were carried out using precipitation technique. Validation of the presence of $C$. quadricarinatus was carried out using PCR development methods and specific primary designs. The results showed that the presence of $C$. quadricarinatus was detected as much as $60 \%$ of all water bodies. Combination of eDNA detection protocol and PCR development method, as well as specific primers designed can be used to detect the presence of $C$. quadricarinatus.
\end{abstract}

Keywords: Cherax quadricarinatus, Environmental DNA, detection, presence, PCR

Abstrak: Cherax quadricarinatus merupakan spesies introduksi yang berasal dari Australia. Siklus hidup yang cepat dan toleransi yang tinggi terhadap lingkungan mengakibatkan $C$. quadricarinatus mudah menginvasi ekosistem perairan. Penelitian ini bertujuan untuk mengaplikasikan teknik eDNA secara cepat untuk deteksi C.quadricarinatus. Teknik ekstraksi eDNA dilakukan dari sampel air dengan menggunakan teknik pengendapan. Validasi keberadaan C.quadricarinatus dilakukan dengan menggunakan metode pengembangan PCR dan desain primer spesifik. Hasil menunjukkan bahwa keberadaan C.quadricarinatus terdeteksi sebanyak $60 \%$ dari keseluruhan badan perairan. Kombinasi protokol deteksi eDNA dan metode pengembangan PCR, serta primer spesifik yang didesain dapat digunakan untuk mendeteksi keberadaan C. quadricarinatus.

Kata kunci : Cherax quadricarinatus, Environmental DNA, deteksi, keberadaan, PCR

\section{Pendahuluan}

Introduksi spesies ke suatu ekosistem yang baru dapat mengganggu stabilitasnya, berkenaan dengan kompetisi antara spesies introduksi dengan spesies asli, penyakit yang dibawa oleh spesies introduksi, dan perubahan rantai makanan (Horwitz 1990). Persebaran spesies introduksi umumnya berkaitan dengan kegiatan manusia. Ada dua peluang persebaran spesies introduksi, yaitu secara sengaja (intentionally introduction), contohnya perdagangan hewan hias (ornamental trade) (Belle et al. 2011) dan budidaya, dan ketidaksengajaan (accidentally introduction), contohnya Podarcis siculus yang terbawa dalam material bangunan dari Eropa menuju ke Amerika Utara (Burke' dan Deichsel 2008). Salah satu spesies introduksi yang 
paling luas distribusinya adalah Cherax quadricarinatus (von Martens 1868). C.quadricarinatus merupakan lobster air tawar endemik dari Australia bagian Utara dan Papua Nugini (Ruscoe 2002). Menurut FAO Fisheries Statistics (2008), budidaya C.quadricarinatus terdapat pada negara tropis maupun subtropis, termasuk Indonesia (Edgerton dan Owens 2005). Sebagai hewan budidaya, spesies ini sangat adaptif pada kondisi perairan yang bervariasi (Karplus et al. 1998). Siklus hidup C. quadricarinatus sangat sederhana dari telur dan lepas ke air kemudian dengan temperatur $20-34^{\circ} \mathrm{C}$ tumbuh dengan cepat tanpa ada fase perkembangan larva (Jones 1995). Akibatnya, C. quadricarinatus tersebar sehingga mudah menginvasi ekosistem perairan (Patoka et al. 2016, 2018).

Keberadaan spesies hewan di lingkungan dapat diketahui dengan pengamatan langsung (direct sign) dan pengamatan tak langsung (indirect sign) (Keeping dan Pelletier 2014). Pengamatan tak langsung (indirect sign) dapat diamati melalui jejakjejak yang ditinggalkan hewan tersebut, salah satunya material genetik (DNA) yang ditinggalkan, yang dikenal dengan Environmental DNA (eDNA). Deteksi eDNAadalah teknik yang digunakan untuk memonitoring hewan di perairan (Ficetola et al. 2008; Jerde et al. 2011). Teknik ini didasarkan pada fakta bahwa semua hewan yang hidup di air meninggalkan DNA melalui kotoran mereka, urine, dan keluapasan kulit (Herder et al. 2014). Penggunaan eDNA sudah diterapkan untuk mendeteksi keberadaan amfibi, reptil, ikan, krustasea, burung air, dan mamalia (Goldberg et al. 2011; Jerde et al. 2011; Olson et al. 2012; Biggs et al. 2015, Minamoto et al. 2015; Wilcox et al. 2015). Takahara et al. (2012) juga menggunakan deteksi eDNA juga dapat digunakan untuk menghitung biomassa dan kelimpahan ikan (Takahara et al. 2012). Dibandingkan teknik sampling secara tradisional, teknik ini dinilai efektif dan efisien dilakukan.

Artikel ini bertujuan untuk mengaplikasikan teknik eDNA secara cepat untuk deteksi C.quadricarinatus. Kami mendesain primer spesifik spesies untuk menvalidasi spesifisitas primer dengan menggunakan metode pengembangan PCR.

\section{Bahan dan Metode}

\section{Preservasi sampel}

Sampel air diambil dari 35 badan perairan tawar di provinsi Jawa Barat (Tabel 1). Masingmasing lokasi badan perairan dibagi menjadi tiga titik sampling, yaitu bagian inlet (daerah pemasukan air), bagian tengah (daerah anatara inlet dan outlet), dan bagian outlet (daerah keluarnya air). Dalam setiap bagian, air diambil beberapa titik menggunakan botol air kemasan yang dibuang isinya. Air dari beberapa botol kemudian disatukan dalam satu botol. Sampel air diawetkan dengan ditambahkan dengan sodium klorida 6M sebanyak $1 / 10$ bagian dan alkohol $96 \%$ sebanyak $1 / 3$ bagian. Sampel air dibawa ke laboratorium dalam suhu ruang. Sesampai di lab, disimpan dalam freezer dengan suhu $-20^{\circ} \mathrm{C}$. Sebagai kontrol negatif digunakan air mineral kemasan. Sebagai kontrol positif digunakan jaringan otot pada periopod $C$. quadricarinatus.

\section{Ekstraksi DNA}

Sampel air disentrifus pada kecepatan $7000 \mathrm{rpm}$ selama 10 menit. Endapan yang terbentuk selanjutnya dibilas dengan alkohol $70 \%$ kemudian diendapkan lagi. Sisa alkohol dalam endapan di uapkan menggunakan vacuum desiccator. Endapan yang diperoleh ditambahkan elution buffer (Thermo Fisher Scientific Inc, US)pada masing-masing sampel. Ekstraksi sampel berupa jaringan periopod C. quadricarinatus dilakukan dengan menggunakan Tissue/Blood DNA Mini Kit (Geneaid, Taiwan).

\section{Polymerase Chain Reaction (PCR)}

Amplifikasi pertama menggunakan primer universal yang dibuat oleh Folmer et al. (1994), yaitu forward LCO1490 (5'GGTCAACAAATCATAAAGATATTGG-3')dan reverse $\mathrm{HCO} 2198$ TAAACTTCAGGGTGACCAAAAAATCA-3') dengan suhu annealing $45^{\circ} \mathrm{C}$. Amplikon kemudian dijadikan cetakan dalam amplifikasi kedua menggunakan primer spesifik CO1 C.quadricarinatus, yaitu forward AF571(5'CAATCACAATTGGGGGTTTT-3') dan reverse AF570 (5'GCTAGAACGGGGAGGGATAA-3'). Primer spesifik ini didesain menggunakan piranti lunak Primer $\quad 3 \quad$ (http://bioinfo.ut.ee/primer30.4.0/primer3/) berdasarkan sekuen utuh CO1 dari C.quadricarinatus (Gambar 1). 


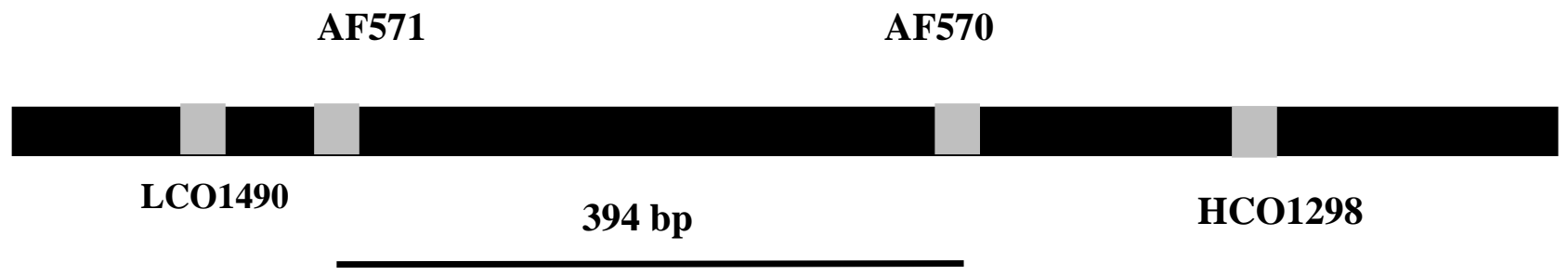

Gambar 1 Skema posisi penempelan amplifikasi pertama (Folmer et al. 1994) dan amplifikasi kedua (AF571 dan AF570)

Visualisasi produk PCR

Produk PCR dielektroforesis menggunakan agarose gel 1,2\% dan divisualisasi dengan menggunakan $U V$ transluminator (Sambrook et al.2001). Target panjang ukuran amplifikasi pertama adalah 710 pasang basa dan amplifikasi kedua adalah 394 pasang basa.

Tabel 1 Daftar lokasi sampel air yang digunakan untuk mendeteksi C.quadricarinatus

\begin{tabular}{llll}
\hline Badan Perairan & Waktu Sampling & Kabupaten/Kota & Kode Sampel \\
\hline Situ Gede Bogor & 15.07 .2017 & Bogor & SG \\
Situ Leutik & 17.07 .2017 & Bogor & LSI \\
Situ Kemang & 18.12 .2017 & Bogor & SKA \\
Situ Jampang & 18.12 .2017 & Bogor & SJM \\
Situ Cicagu & 18.12 .2017 & Bogor & SCG \\
Situ Borcess & 18.12 .2017 & Bogor & SBR \\
Danau Dora & 26.11 .2017 & Cibinong & SCK \\
Situ Cikaret & 26.11 .2017 & Cibinong & SCI \\
Situ Cibinong & 13.01 .2018 & Cibinong & SCT \\
Situ Citayam & 13.01 .2018 & Citayam & SBT \\
Situ Bentenan & 13.01 .2018 & Cibinong & SJJ \\
Situ Jatijajar & 13.01 .2018 & Depok & SCL \\
Situ Cilodong & 13.01 .2018 & Depok & SRB \\
Situ Rawa Besar & 13.01 .2018 & Depok & SGB \\
Situ Gede Bekasi & 21.01 .2018 & Bekasi & DR \\
Danau Cibeureum & 21.01 .2018 & Bekasi & SKJ \\
Danau Resinda & 22.01 .2018 & Karawang & WJ \\
Situ Kamojing & 01.02 .2018 & Karawang & SCP \\
Waduk Jatiluhur & 06.12 .2017 & Purwakarta & SCD \\
Situ Cipanten & 01.02 .2018 & Majalengka & WJG \\
Situ Cikuda & 01.02 .2018 & Majalengka & WD \\
Waduk Jatigede & 01.02 .2018 & Sumedang & TR \\
Waduk Dharma & 17.08 .2017 & Kuningan & SGT \\
Telaga Remis & 01.02 .2018 & Kuningan & SBO \\
Situ Gede Tasikmalaya & 05.12 .2017 & Tasikmalaya & SCM \\
Situ Bojong & 05.12 .2017 & Tasikmalaya & SP \\
Situ Cibeureum & 05.12 .2017 & Tasikmalaya & \\
Situ Bagendit & 17.08 .2017 & Garut & Ciamis \\
Situ Lengkong & 17.08 .2017 & & \\
\hline & & & \\
& & &
\end{tabular}




\begin{tabular}{llll}
\hline Badan Perairan & Waktu Sampling & Kabupaten/Kota & Kode Sampel \\
\hline Situ Cisanti & 18.08 .2017 & Pengalengan & SC \\
Situ Ciburuy & 05.12 .2017 & Padalarang & SCB \\
Situ Patenggang & 06.12 .2017 & Bandung & SPT \\
Situ Cileunca & 18.08 .2017 & Bandung & SCC \\
Waduk Cirata & 06.12 .2017 & Cianjur & WC \\
Danau Lido & 11.05 .2017 & Sukabumi & LD \\
\hline
\end{tabular}

\section{Hasil dan Pembahasan}

Keberadaan C. quadricarinatus berhasil dideteksi sebanyak $60 \%$ dari keseluruhan badan perairan dengan menggunakan teknik eDNA (Tabel 1). Ficetola et al. (2008) mengemukakan bahwa teknik ini adalah teknik yang menjanjikan dalam ekologi. Menurut Biggs et al. (2014) tingkat akurasi deteksi spesies menggunakan teknologi eDNA untuk amfibi mencapai 99,3\%. Akurasi deteksi ini jauh lebih besar disbanding metode perangkap (76\%), survei langsung keberadaan individu (75\%) ataupun survei telur (44\%).

Pemulihan DNA selular dan ekstraselular dalam air dapat dilakukan dengan teknik pengendapan alkohol maupun teknik filtrasi penyaringan (Deiner et al. 2015). Kedua teknik mempunyai kemampuan yang sama dalam mendeteksi ada tidaknya spesies. Teknik pengendapan menggunakan alkohol jauh lebih murah dibandingkan filtrasi. Kendala utamanya adalah pada transportasi sampel air dari situs sampling ke laboratorium. Sebaliknya, teknik filtrasi jauh lebih mahal tetapi mudah ditransportasikan. Kendala lain dari teknik pengendapan adalah jumlah DNA total yang dihasilkan lebih rendah dibandingkan metode filtrasi (Deiner et al. 2015).

Ketika jumlah DNA total yang didapat rendah, maka perlu dilakukan peningkatan kepekaan dengan menambah sampel air yang diendapkan atau filtrasi, dan meningkatkan sampel DNA dalam terhadap uji PCR untuk mengetahui sensitivitas (Deiner et al. 2015). Pada penelitian ini, aplikasi PCR yang dikembangkan adalah primer universal menggunakan suhu annealingyang rendah $\left(47^{\circ} \mathrm{C}\right)$ yang kemudian amplikonnya dijadikan cetakan untuk diamplifikasi menggunakan primer spesifik spesies target.

Berdasarkan Tabel 2, pada $1^{\text {st }}$ PCR menggunaan primer universal (Folmeret al., 1994) menghasilkan pita amplikon yang tidak tunggal atau tidak spesifik hanya spesies target. Setelah amplikon $1^{\text {st }}$ PCR tersebut dijadikan cetakan dalam $2^{\text {nd }}$ PCR menggunakan primer yang spesifik maka terjadi seleksi terhadap amplikon awal sehingga hanya spesies target saja yang berhasil diamplifikasi. PCR standar tidak cukup sensitif untuk mendeteksi target spesies dengan akurat dari sampel eDNA (Calsamiglia et. al 1999). Hal tersebut dikarenakan pada $1^{\text {st }}$ PCR, membutuhkan suhu annealing (penempelan primer) yang lebih rendah, sehingga oligonukleotida kurang spesifik berikatan DNA cetakan (template) (Wu et al. 1991). Pada $2^{\text {nd }}$ PCR membutuhkan suhu annealing (penempelan primer) yang lebih tinggi, sehingga oligonukleotida lebih spesifik berikatan DNA cetakan (template) (Wu et al. 1991).

Kombinasi protokol eDNA dan aplikasi PCR menggunakan primer DNA yang didesain secara spesifik mampu mendeteksi keberadaan spesies di suatu perairan jauh lebih baik dibanding metode deteksi keberadaan secara konvensional (bioasessment conventional) (Lim et al. 2016).

Tabel 2 Deteksi C.quadricarinatus menggunakan PCR ( $1^{\text {st }}$ PCR $=$ amplifikasi pertama, dan $2^{\text {nd }}$ PCR = amplifikasi kedua)

\begin{tabular}{|c|c|c|c|c|c|c|c|}
\hline \multirow[b]{2}{*}{ Lokasi } & \multicolumn{2}{|l|}{ Inlet } & \multicolumn{2}{|c|}{ Tengah } & \multicolumn{2}{|c|}{ Outlet } & \multirow{2}{*}{$\begin{array}{l}\text { Sampel air yang } \\
\text { terdeteksi }\end{array}$} \\
\hline & $\begin{array}{l}\text { 1st } \\
\text { PCR }\end{array}$ & $\begin{array}{l}\text { 2nd } \\
\text { PCR }\end{array}$ & $\begin{array}{l}\text { 1st } \\
\text { PCR }\end{array}$ & $\begin{array}{l}\text { 2nd } \\
\text { PCR }\end{array}$ & $\begin{array}{l}\text { 1st } \\
\text { PCR }\end{array}$ & $\begin{array}{l}\text { 2nd } \\
\text { PCR }\end{array}$ & \\
\hline Situ Gede Bogor & + & + & + & + & - & - & $\checkmark$ \\
\hline Situ Leutik/LSI & + & + & + & - & - & - & $\checkmark$ \\
\hline Situ Kemang & + & - & - & - & + & - & \\
\hline
\end{tabular}




\begin{tabular}{|c|c|c|c|c|c|c|c|}
\hline \multirow[b]{2}{*}{ Lokasi } & \multicolumn{2}{|l|}{ Inlet } & \multicolumn{2}{|c|}{ Tengah } & \multicolumn{2}{|c|}{ Outlet } & \multirow{2}{*}{$\begin{array}{l}\text { Sampel air yang } \\
\text { terdeteksi }\end{array}$} \\
\hline & $\begin{array}{l}\text { 1st } \\
\text { PCR }\end{array}$ & $\begin{array}{l}\text { 2nd } \\
\text { PCR }\end{array}$ & $\begin{array}{l}\text { 1st } \\
\text { PCR }\end{array}$ & $\begin{array}{l}\text { 2nd } \\
\text { PCR }\end{array}$ & $\begin{array}{l}\text { 1st } \\
\text { PCR }\end{array}$ & $\begin{array}{l}\text { 2nd } \\
\text { PCR }\end{array}$ & \\
\hline Situ Jampang & + & - & - & - & + & - & \\
\hline Situ Cicagu & - & - & + & - & + & + & $\checkmark$ \\
\hline Situ Borcess & + & - & + & - & + & - & \\
\hline Danau Dora & + & - & + & + & + & - & $\checkmark$ \\
\hline Situ Cikaret & + & + & + & + & + & - & $\checkmark$ \\
\hline Situ Cibinong & + & + & + & - & - & - & $\checkmark$ \\
\hline Situ Citayam & + & - & + & + & + & + & $\checkmark$ \\
\hline Situ Bentenan & + & - & - & - & - & - & \\
\hline Situ Jatijajar & + & - & - & - & + & - & \\
\hline Situ Cilodong & + & - & - & - & + & + & \\
\hline Situ Rawa Besar & + & + & + & - & - & - & $\checkmark$ \\
\hline Situ Gede Bekasi & - & - & - & - & + & - & \\
\hline Danau Cibeureum & - & - & - & - & - & - & \\
\hline Danau Resinda & + & + & + & - & + & - & $\checkmark$ \\
\hline Situ Kamojing & - & - & - & - & + & + & $\checkmark$ \\
\hline Waduk Jatiluhur & - & - & + & - & + & + & $\checkmark$ \\
\hline Situ Cipanten & + & + & - & - & + & + & $\checkmark$ \\
\hline Situ Cikuda & + & - & + & + & + & + & $\checkmark$ \\
\hline Waduk Jatigede & - & - & - & - & + & - & \\
\hline Waduk Dharma & + & - & + & - & + & + & $\checkmark$ \\
\hline Telaga Remis & + & + & + & + & + & - & $\checkmark$ \\
\hline Situ Gede Tasikmalaya & - & - & + & - & - & - & \\
\hline Situ Bojong & + & - & - & - & + & - & \\
\hline Situ Cibeureum & + & - & - & - & + & - & \\
\hline Situ Bagendit & + & + & + & - & + & + & $\checkmark$ \\
\hline Situ Lengkong Panjalu & + & - & + & + & - & - & $\checkmark$ \\
\hline Situ Cisanti & - & - & - & - & + & - & \\
\hline Situ Ciburuy & + & - & + & + & - & - & $\checkmark$ \\
\hline Situ Patenggang & + & + & + & - & - & - & $\checkmark$ \\
\hline Situ Cileunca & + & + & + & + & + & - & $\checkmark$ \\
\hline Waduk Cirata & + & - & - & - & + & - & \\
\hline Danau Lido & + & + & + & + & + & + & $\checkmark$ \\
\hline
\end{tabular}

\section{Kesimpulan}

Dari hasil dan pembahasan dapat disimpulkan bahwa keberadaan C.quadricarinatus terdeteksi sebanyak $60 \%$ dari keseluruhan badan perairan. Kombinasi protokol deteksi eDNA dan metode pengembangan PCR, serta primer spesifik yang didesain dapat digunakan untuk mendeteksi keberadaan C. quadricarinatus.

\section{Daftar Pustaka}

Belle, C.C; Jason, Q.H.W; Yeo, D, C,J ; Tan, S.H; Heok, H.T; Clews, E dan Peter, A. T. 2011. Ornamental trade as a pathway for Australian redclaw crayfish introduction and establishment. Aquat Biol 12: 69-79.

Biggs, J; Ewald, N; Valentini,A; Gaboriaud, C; Dejean, T; Griffiths, R.A; Foster, J; Wilkinson, J.W; Arnell, A; Brotherton, P; 
Williams, P dan Dunn, F. 2014. Using eDNA to develop a national citizen science-based monitoring programme for the great crested newt (Triturus cristatus). Biological Conservation 183: 19-28.

Burke, R.L; Goldberg, S.R; Bursey, C.R; Perkins, S.L dan Andreas, P.T. 2007. Depauperate Parasite Faunas in Introduced Populations of Podarcis (Squamata: Lacertidae) Lizards in North America. Journal of Herpetology 41 (4):755-757.

Calsamiglia, M; Pijoan, C dan Trigo A. 1999. Application of a Nested Polymerase Chain Reaction Assay to Detect Mycoplasma hyopneumoniae from Nasal Swabs. J Vet Diagn Invest 11: 246-251.

Deiner, K; Walser, J.C; Mächler, E dan Altermatt, F. 2015. Choice of capture and extraction methods affect detection of freshwater biodiversity from environmental DNA. Biological Conservation 183: 53-63.

Edgerton, B.F dan Owens, L. 1999. Histopathological surveys of the redclaw freshwater crayfish, Cherax quadricarinatus, in Australia. Aquaculture 180: 23-40.

Ficetola, G.F; Miaud, C; Pompanon, F dan Taberlet, P. 2008. Species detection using environmental DNA from water samples. Biol. Lett. 4: 423-425.

Folmer, O; Black, M; Hoeh, W; Lutz, R dan Vrijenhoek, R. 1994. DNA primers for amplification of mitochondrial cytochrome c oxidase subunit I from diverse metazoan invertebrates. Molecular Marine Biology and Biotechnology 3(5): 294-299.

Goldberg, C.S; Pilliod, D.S; Arkle, R.S dan Waits, L.P. 2011. Molecular detection of vertebrates in stream water: a demonstration using Rocky Mountain tailed frogs and Idaho giant salamanders. PloS One 6, e22746.

Herder, J.E. A. Valentini, E. Bellemain, T. Dejean, J.J.C.W. van Delft, P.F. Thomsen dan P. Taberlet, 2014. Environmental DNA - a review of the possible applications for the detection of (invasive) species. Stichting RAVON, Nijmegen. Report 2013-104.

Horwitz, P. 1990. The Translocation of Freshwater Crayfish in Australia: Potential Impact,
TheNeed for Control and Global Relevance. Bio Con 54: 291-305.

Jerde, C.L; Mahon, A.L; Chadderton, W.L dan Lodge, D.M. "Sight-unseen" detection of rare aquatic species using environmental DNA. Conservation Letters 4: 150-157.

Jones, C.M. 1995. Effect of temperature on growth and survival of the tropical freshwater crayfish, Cherax quadricarinatus (von Martens) (Decapoda, Parastacidae). Freshwater Crayfish 8: 391-398.

Karplus, I; Zoran, M; Milstein, A; Harpaz, S; Eran, Y; Joseph, D dan Sagi, A. 1998. Culture of the Australian red-claw crayfish (Cherax quadricarinatus) in Israel. III. Survival in earthen ponds under ambient winter temperatures. Aquaculture 166: 259-267.

Keeping D dan Pelletier, R. 2014. Animal density and track counts: understanding the nature of observations based on animal movements. PLos One : 9(5) : e96598.

Lim, N.K.M; Tay, Y.C; Srivathsan, A; Tan, J.W.T; Kwik, J.T.B; Balouglu, B; Meier, R dan Ye, D.C.J. 2016. Next-generation freshwater bioassessment: eDNA metabarcoding with a conserved metazoan primer reveals species-rich and reservoirspecific communities. R. Soc. Open Sci. 3: 160635.

Lin T, Liu, F dan Liao, I. 1999. Experiment on adaptation of Australian crayfish to selected environmental factors. J Taiwan Fish Res 7: 73-85.

Minamoto, T; Yamanaka, H, Takahara, T; Honjo, M. N dan Kawabata, Z. 2012. Surveillance of fish species composition using environmental DNA. Limnology 13:193197

Olson, Z.H.; Briggler, J.T dan Williams, R.N. 2012. An eDNA approach to detect eastern hellbenders (Cryptobranchus a. alleganiensis) using samples of water. Wildl. Res. 39: 629-636.

Patoka, J.; Wardiatno, Y.; Yonvitner; Kuř́iková, P.; Petrtýl, M dan Kalous, L. 2016. Cherax quadricarinatus (von Martens) has invaded Indonesian territory west of the Wallace Line: evidences from Java. Knowledge and Management of Aquatic Ecosystems 417: 39. 
Patoka, J.; Wardiatno, Y.; Mashar, A.; Yonvitner; Wowor, D.; Jerikho, R.; Takdir, M.; Purnamasari, L.; Petrtýl, M.; Kalous, L; Kouba, A. dan Bláha, M. 2016. Redclaw crayfish, Cherax quadricarinatus (von Martens, 1868), widespread throughout Indonesia. BioInvasions Records 7(2): 185189.

Ruscoe, I. 2002. Fishnote 2 : Redclaw Crayfish Aquaculture. Australia : Darwin Fisheries Northern Territory Government.

Takahara, T., Minamoto, T. dan Doi, H., 2013. Using Environmental DNA to Estimate the Distribution of an Invasive Fish Species in Ponds. PLoS One 8, e56584.

Wilcox, T.M; McKelvey, K.S; Young, M.K; Jane, S.F; Low,e, W.H; Whiteley, A.R dan Schwartz, M. K. 2013. Robust detection of rare species using environmental DNA: the importance of primer specificity. PLos One 8 (3): e59520

Wu, D.Y; Ugozzoli, L; Pal, B.K; Qian, J dan Wallace, R.B. 1991. The effect of emperature and oligonucleotide primer length on the specificity and efficiency of amplification by the polymerase chain reaction. DNA Cell Biol. 10(3): 233-238. 